ROCZNIKI TEOLOGICZNE

Tom LXVI, zeszyt 8 -2019, s. 79-90

DOI: http://dx.doi.org/10.18290/rt.2019.66.8-6

REV. BOGUSŁAW MIGUT

\title{
THE EUCHARIST \\ AS A SACRAMENT OF CHRISTIAN INITIATION: HISTORICAL-LITURGICAL ASPECT
}

\begin{abstract}
A b stract. The author of the article takes on the issue of the place of the Eucharist in Christian initiation in its historical-liturgical aspect. He draws attention to the fundamental awareness during the first millennium of the unity and proper sequence of the sacraments of Christian initiation: Baptism-Confirmation-Eucharist. Its disappearance can be noted at the turn of the $12^{\text {th }}$ and $13^{\text {th }}$ centuries, together with the practice of Holy Communion for children. He points out that during the post-Tridentine era the order of conferring the sacraments of initiation was reversed: baptism-Eucharist-confirmation, and this state was perpetuated by the decree Quam Singulari (1910), which separated the sacraments from each other even more. The author draws attention to the two models of Christian initiation rising from Vatican Council II, the Ordo Baptismi Parvulorum (1969) emphasizing the practice of baptism of infants followed several years later by First Communion and at a later time, confirmation; and the Ordo Initiationis Christianae Adultorum (1972), concerning preparation for confirmation and the Eucharist for adults. Referring to the views of Salvatore Marsili, the author of the article makes an evaluation of these models. He sees the one connected to the Ordo Initiationis Christianae Adultorum as well-balanced, with its focal point being the Eucharist. This model retains the theological sequence of the sacraments and treats the Eucharist, rather than confirmation, as the fullness and summit of Christian initiation. It also allows for a proper designation of baptism as the sacrament of inclusion into the mystery of salvation but still requiring confirmation and the Eucharist for full inclusion in the reality of the Church.
\end{abstract}

Key words: Eucharist; Baptism; Confirmation; Christian initiation; Jesus Christ; Church, Salvatore Marsili O.S.B.

Rev. Dr. hab. BogusŁaw Migut, Prof. at KUL — John Paul II Catholic University of Lublin, Faculty of Theology, Institute of Theological Sciences, Section of Liturgy and Homiletics; Department of Theology of Liturgy; address for correspondence: Aleje Racławickie 14, 20-950 Lublin; e-mail: bmigut@kul.pl

Ks. dr hab. BogusŁaw Migut, prof. KUL — Katolicki Uniwersytet Lubelski Jana Pawła II, Wydział Teologii, Instytut Nauk Teologicznych, Sekcja Liturgiki i Homiletyki, Katedra Teologii Liturgii; adres do korespondencji: Aleje Racławickie 14, 20-950 Lublin; e-mail: bmigut@kul.pl 
The topic of the Eucharist as a sacrament of Christian initiation is rather poorly developed. Western theological tradition concerning the Eucharis is concentrated chiefly on the real and substantial presence of Christ within it, or on the sacrificial dimension of the Mass. ${ }^{1}$ The scarcity of Christian initiation of adults in the Church has resulted in a lack of interest in this subject. Even after its restoration, however, the topic is still not discussed in-depth. The earliest published pieces on the theme of Christian initiation confine themselves to stating that the Eucharist belongs to its sacraments along with baptism and confirmation. At best they take one more step and state that the Eucharist completes Christian initiation. ${ }^{2}$ In this context, the research problem is the question of in what way the Eucharist participates in the process of Christian initiation, and why it is its summit.

In endeavoring to give the fullest answer to this question, it is necessary first to take a closer look at the place of the Eucharist in Christian initiation in historical outline, and then in the two models of Christian initiation in use today, to which we can give the working names of "theological" and "pedagogical," referring in this mainly to the publications of Salvatore Marsili. Achieving a comprehensive answer to the research question posed requires completing the theological-liturgical aspect with the theological-liturgical concept, which is done in a separate article. ${ }^{3}$

\section{HISTORICAL OVERVIEW OF CHRISTIAN INITIATION AND THE PLACE OF THE EUCHARIST IN IT}

During the first millennium of Christianity, as Rev. Pierangelo Muroni states, on the basis of the thorough research of Rev. Maciej Zachary, ${ }^{4}$ we

\footnotetext{
${ }^{1}$ Cf. Edward J. Kilmartin, "Sacramental Theology: The Eucharist in Recent Literature," Theological Studies 32 (1971), no. 2: 233-277, especially 233.

${ }^{2}$ It should be pointed out that in this respect three Polish publications form an exception: Andrzej Megger, "Eucharystia w procesie wtajemniczenia chrześcijańskiego," Roczniki Teologiczne 63 (2016), fasc. 8: 21-41; Helmut Jan SOBECZKO, "Eucharystia sakramentem permanentnej inicjacji chrześcijańskiej," in Misterium Eucharystii. Teologia - liturgia - ekumenizm. Encyklika Jana Pawła II "Ecclesia de Eucharistia," ed. Władysław Nowak (Olsztyn: Wydawnictwo Uniwersytetu Warmińsko-Mazurskiego, 2004), 52-70; Félix María Arocena Solano, "Eucharystia - pełnia inicjacji chrześcijańskiej," in Żyć w Chrystusie wedtug Ducha. Teologia sakramentów wtajemniczenia chrześcijańskiego, (Modlitwa Kościoła 17), ed. Krzysztof Porosło (Tyniec: Wydawnictwo Benedyktynów, 2014), 153-168.

${ }^{3}$ This article appeared in Liturgia Sacra this year.

${ }^{4}$ Cf. Maciej ZACHARA, L'ordine dei sacramenti dell'iniziazione cristiana. La storia del loro conferimento nella liturgia romana fino alla fine del XIII secolo, (Tesi - Pontificio Ateneo San
} 
were dealing with the original unity and order of the sacraments of Christian initiation as they came from Sacred Scripture and the teachings of the Fathers of the Church and have been uninterruptedly practiced by the Eastern Church. This reflected the theological unity of the three sacraments of initiation, realized in liturgical practice, where the three sacraments were given together, and in the following order: baptism, confirmation, Eucharist. ${ }^{5}$ We find the first description of conferring the sacraments of baptism, confirmation, and Eucharist during the Easter Vigil, after catechetical preparation, in the Traditio Apostolica of Pseudo-Hippolytus of Rome, being a witness to the unity of these sacraments. Just as in Hippolytus, in the first centuries these three sacraments were conferred within the framework of one liturgical celebration, in which it was sometimes difficult to separate the rite of baptism from the rite of confirmation. Such a distinction was basically possible only when they were conferred by different ministers, which came to take place more and more frequently after the $5^{\text {th }}$ century in the West. ${ }^{6}$ The reasons for this were mostly of a pastoral nature, connected to the locality in which the initiation took place. If it was held in the place where the bishop was, it continued to be celebrated in one liturgical celebration and in the original order of baptism, confirmation, Eucharist. Rome is an example of this practice in the period of the $7^{\text {th }}$ to $9^{\text {th }}$ centuries.

If the Christian initiation took place in locations far from the bishop's seat, where the presence of a bishop was rare, normally connected to a pastoral visit, the Christian initiation would take place in two stages-first baptism and Communion, and after some time, on the occasion of the bishop's coming, confirmation. This resulted in a continually growing number of Christians (including children) receiving the sacraments of initiation in this way, and this in consequence lead not only to the dissolution of the unity of the celebration, but also to the diminishing of the importance of the sacrament of confirmation (to the point of seeing it almost as optional) as well as of awareness of the bonds between baptism, confirmation, and the

Anselmo. Pontificio Istituto Liturgico 299) (Lublin: Drukarnia Liber, 2003); IDEM, "Il sacramento della confermazione nel primo millennio in Occidente," in La cresima. Atti del VII Congresso Internazionale di Liturgia. Roma, Pontificio Istituto Liturgico, 6-8 maggio 2004, (Studia Anselmiana, 144. Analecta liturgica, 26), ed. Ephrem Carr (Roma: Pontificio Ateneo San Anselmo, 2007), 103-132.

${ }^{5}$ Cf. Pierangelo Muroni, "Kolejność udzielania sakramentów inicjacji chrześcijańskiej," in Żyć w Chrystusie wedtug Ducha. Teologia sakramentów wtajemniczenia chrześcijańskiego, 292.

${ }^{6}$ Cf. ibid, 293-294. On the theological difficulties of recognizing confirmation as a separate sacrament cf. J.N.D. Kelly, Początki doktryny chrześcijańskiej, trans. Julia Mrukówna (Warszawa: Instytut Wydawniczy PAX, 1988), 160-161. 
Eucharist. ${ }^{7} \mathrm{Up}$ until the end of the $10^{\text {th }}$ century, delayed confirmation was seen as an irregularity. This is clearly expressed in the Ordo Romanus XI (no. 102) of the $7^{\text {th }}$ century, where there is an injunction not to delay confirmation. Also noteworthy is that in Italy the network of episcopal Sees made possible frequent visits from the bishop and his conferring of the sacrament of confirmation. ${ }^{8}$ The model of its celebration of Alcuin and Rabanus Maurus of the milieu of Charlemagne can be seen as a departure from the original unity of the sacraments of initiation, consisting of the confirmation of neophytes a week after baptism and First Communion, as a consequence of a pneumatological interpretation of the purification of holy baptism. This manner of conferring the sacraments of initiation was assigned only to the community of Charlemagne and does not presuppose any general change in the order of initiation. ${ }^{9}$ Amalarius of Metz in his Liber Officialis describes confirmation conferred during the Easter Vigil, but also speaks of the practice consisting of bishops, during visitations to parishes, on the model of the Apostles Peter and John, coming to the baptized to lay hands on them (Acts 8:17). ${ }^{10}$

Awareness of the unity and proper order of the sacraments of Christian initiation, despite differences in pastoral practices, remained quite strong up until the end of the first millennium. For the most part the witness of the East and of the West show that adults and children made their First Communion directly after baptism and confirmation (Apostolic Constitution VIII, 13, 14; writings of St. Cyprian and of St. Augustine; the Sacramentarium Gelasianum, and the Ordines Romani from the $5^{\text {th }}$ century to the late Middle Ages). ${ }^{11}$ Be this as it may, even in the first millennium, beginning in the $5^{\text {th }}$ century, mainly for pastoral reasons (lack of the bishop for conferral), the Eucharist was sometimes given directly after baptism and before confirmation. The Ordines Romani beginning in the $10^{\text {th }}$ century bear witness to this, where it is mentioned that in the absence of the bishop at the time of conferral of baptism (at that time most often of children), the presbyter gives Communion. ${ }^{12}$ The Mozarabic rite for many centuries kept the practice of

\footnotetext{
${ }^{7}$ Cf. Angelo LAmERI, "Il sacramento della confermazione. Evoluzione storica della prassi sacramentale dell'iniziazione cristiana e criteri teologico-pastorali circa la scelta dell'età di conferimento," Rivista liturgica 91 (2004): 89; MURONI, "Kolejność udzielania sakramentów," 296.

${ }^{8}$ Cf. Czesław Krakowiak, Bierzmowanie sakrament inicjacji chrześcijańskiej (Lublin: Wydawnictwo Archidiecezji Lubelskiej, 2005), 31-32.

${ }^{9} \mathrm{Cf}$. ZACHARA, Il sacramento della confermazione, 126-129.

${ }^{10}$ Cf. KRAKOWIAK, Bierzmowanie sakrament inicjacji chrześcijańskiej, 32-33.

${ }^{11}$ Cf. ibid., 34.

${ }^{12}$ Cf. Les „Ordines Romani” du haut moyen âge, vol. 2: Les textes (Ordines I-XIII), ed. Michel Andrieu (Louvain: Spicilegium Sacrum Lovaniense, 1971), 401-404.
} 
combining the three sacraments, even when conferring them upon children. At the Easter Vigil the baptized children received Communion in the baptistry and were then taken home, and the newly baptized adults participated in the Eucharist. ${ }^{13}$ During the $12^{\text {th }}$ century in Rome itself, at the Lateran basilica, there was a special Communion rite for infants and it consisted of a deacon, after Mass, dipping a finger into the Precious Blood and giving it to such children to suck. This Roman custom was confirmed by Pope Paschal II (1112-1114), by dividing those receiving Communion into capaces (those capable of receiving Communion under both species) and incapaces (children receiving Communion under the species of wine). ${ }^{14}$ The practice of giving Communion to children was also affirmed by theologians of the time. ${ }^{15}$

From the turn of the $12^{\text {th }}$ and $13^{\text {th }}$ centuries a ritual disappearance came about both of the union of the sacraments of initiation and the practice of giving Holy Communion to children. Witnesses to the separation of confirmation from the rite of baptism are the Pontificale Romanae Curiae ${ }^{16}$ and the Durand Pontifical, ${ }^{17}$ which place these rites at first among the blessings of liturgical vestments and the dedication of bread, and then among the rites for blessings and the consecration of persons. ${ }^{18}$ The disappearance of Holy Communion for children was connected with the discussion on whether persons not having the use of reason may receive the Eucharist and whether an obligation exists to give Communion to children. On the first question, St. Thomas Aquinas gave a negative answer: "it is not necessary to give Holy Communion to children immediately after birth [...] But when children once begin to have some use of reason so as to be able to conceive some devotion for the sacrament, then it can be given to them." ${ }^{19}$ As far as an obligation to

\footnotetext{
${ }^{13} \mathrm{Cf}$. Le Liber ordinum en usage dans l'église wisigothique et mozarabe d'Espagne du cinquième au onzième siècle. Publié pour la première fois, ed. Marius Férotin (Paris: FirminDidot, 1904), 217-218; Gabriel Miquel RAMIS, La iniciación cristiana en la liturgia hispánica (Bilbao: Estudios Grafite, 2001), 101-102; AROCENA SOLANO, Eucharystia - petnia inicjacji chrześcijańskiej, 154.

${ }^{14}$ Cf. Michele Maccarrone, "L'unità del battesimo e della Cresima nelle testimonianze della liturgia Romana dal III al XVI secolo," Lateranum 51 (1985): 101.

${ }^{15}$ Cf. KRAKOWIAK, Bierzmowanie sakrament inicjacji chrześcijańskiej, 35.

${ }^{16}$ Cf. Les pontifical Romain au moyen-âge, vol. 1: Le Pontifical de la Curie Romaine au XIIIe siècle, (Studi e Testi 87), ed. Michel Andrieu (Città del Vaticano: Biblioteca Apostolica Vaticana, 1940), chapters. XXXIII-XXXV, 451-453.

${ }^{17}$ Le pontifical Romain au moyen-âge, vol. 3: Le Pontifical de Guillaume Durand, (Studi e Testi 88), ed. Michel Andrieu (Città del Vaticano: Biblioteca Apostolica Vaticana, 1940), 333.

${ }^{18}$ Cf. Muroni, “Kolejność udzielania sakramentów,” 299-300.

${ }^{19}$ St. Thomas Aquinas, Summa Theologiae, III q. 80 a. 9, New Advent, accessed 17.06.2019, http://www. http://www.newadvent.org/summa/4080.htm\#article9.
} 
give Holy Communion to children, the answer is also in the negative, citing the necessity of the use of reason. In effect then the sacraments of initiation are conferred separately from each other and First Communion and confirmation began to be preceded by catechesis, in order to allow for the use of reason. Still, in the $13^{\text {th }}$ century, awareness of the proper order of the sacraments of initiation had not disappeared. Zachara recalls the fact that some of the synods of this era, for example Lambeth (1231) stipulated that Communion could not be received without confirmation being conferred first, with the exception of danger of death or serious harm. ${ }^{20}$ At the same time there was a deepening conviction as to the necessity of extended, solid preparation for confirmation and First Communion, so that children would be able to grasp the sense of what they were receiving and what they were approaching. In the late Middle Ages some local synods therefore designated the exact age for confirmation (usually from seven up to twelve years old) ${ }^{21}$ All of this became a task for the Council of Trent, which in its XXI session (1562) took up the topic of Holy Communion for children, teaching that "little children who have not attained the use of reason are not by any necessity bound to the sacramental communion of the Eucharist; for having been regenerated by the laver of baptism and thereby incorporated with Christ, they cannot at that age lose the grace of the sons of God already acquired." 22 Immediately afterwards, the Council adds a statement that clearly references the original custom connected with the unity and order of administering the sacraments of initiation: "Antiquity is not therefore to be condemned, however, if in some places it at one time observed that custom. For just as those most holy Fathers had acceptable ground for what they did under the circumstances, so it is certainly to be accepted without controversy that they regarded it as not necessary to salvation." 23 The Council of Trent had to take on another problem, that of the sequence for receiving the sacraments. In its Catechism for Parish Priests ${ }^{24}$ of 1566 it is recommended

\footnotetext{
${ }^{20} \mathrm{Cf}$. ZACHARA, L'ordine dei sacramenti, 248.

${ }^{21}$ Cf. Muroni, "Kolejność udzielania sakramentów," 300-301.

${ }^{22}$ EWTN. Global Catholic Network, accessed 17.06.2019, http://www.ewtn.com/library/ councils/trent21.htm. The Latin and Polish versions: Dokumenty Soborów Powszechnych. Tekst taciński i polski, vol. 4/2: (1511-1870) Lateran V, Trydent, Watykan I, ed. Arkadiusz Baron and Henryk Pietras (Kraków: Wydawnictwo WAM, 2007), 611.

${ }^{23}$ Ibid.

${ }^{24}$ Catechismus ex decreto Concilii Tridentini ad parochos Pii Quinti Pont. Max. iussu editus ad editionem Romae a.d. MDLXVI. publici iuris factam accuratissime expressus: cum s. rev. consistorii catholici per regnum saxoniae aprobatione (Lipsiae: Ex Officina Bernhardi Tauchnitz, 1865) (Polish trasnlation: Katechizm rzymski z wyroku świętego Soboru Trydenckiego
} 
that confirmation not be conferred upon children before they acquire the ability of independent thinking. Because of this the catechism recommended that confirmation be conferred between the ages of seven to twelve years old. The Catechism of Trent points to the necessity of preparation both for confirmation and for the Eucharist, in which for the Eucharist is required distinguishing between normal bread and the Eucharistic Bread, and for confirmation, knowledge on the doctrine and effects of this sacrament. ${ }^{25}$ The teaching of the Catechism of Trent and post-Tridentine provincial synods resulted in not only a lengthening of the time of preparation catechesis, but in effect reversed the order of conferral of the sacraments of Christian initiation. And thus the Eucharist, which up until that time had been treated as the summit of initiation, began to be conferred after baptism, but before confirmation. Confirmation on the other hand became the third sacrament of initiation, increasingly understood not as an element of initiation, but as the sacrament of adulthood. This practice was additionally strengthened by Jansenism and the situation in France after the French Revolution. ${ }^{26}$

An important moment in the history of Christian initiation was the pontificate of Pope Pius X, when the decree of the Sacred Congregation for the Sacraments published the decree Quam singulari (1910), which lowered the age of First Communion to children of seven years old. This decree also emphasized, making reference to Lateran Council IV of 1215, that at the time of First Communion begins the obligation of fulfilling the instructions concerning confession and Communion. The decree also allowed confirmation to be conferred at the age of seven years. Pius $\mathrm{X}$ intended in this way to return and keep to the traditional order of conferring the sacraments of initiation. In reality however the decree did not change, and even perpetuated, the existing custom of conferring confirmation at the age of twelve or older, and precipitated only First Holy Communion. As a result of these decisions the sacraments of Christian initiation became even more sharply divided from each other, although it is worthwhile and right to recognize the earlier admission of children to full participation in Holy Mass. ${ }^{27}$

Not until the Constitution on the Sacred Liturgy Sacrosanctum Concilum (SC 64-72) and the Decree on the Missionary Activity of the Church Ad

ułożony z rozkazu Piusa V Papieża i od Klemensa XIII szczególnie zalecony, vol. 1-3 (Warszawa: [Drukarnia Kommissyi Rząd. W. R. i O. P.], 1827); the English version: The Eclipse of the Church, accessed 17.06.2019, https://www.eclipse ofthechurch.com/Library/catechism_of_trent.pdf.

${ }^{25}$ Cf. Muroni, "Kolejność udzielania sakramentów," 302.

${ }^{26}$ Cf. ibid., 302-309.

${ }^{27}$ Cf. ibid., 313-314. 
Gentes (AG 14-15) was there a fundamental renewal of Christian initiation. Vatican Council II renewed the catechumenate and contributed to its revival in the Church.

\section{THE PLACE OF THE EUCHARIST IN TWO MODELS OF CHRISTIAN INITIATION}

As a result of the liturgical reforms of Vatican Council II, two models of Christian initiation came about, connected to two rituals: The Ordo Baptismi Parvulorum of 1969 and the Ordo Initiationis Christianae Adultorum of 1972. The current situation in the western Church is quite diverse. Most often, however, we are dealing with infant baptism, followed by First Communion several years later, and at a later time, confirmation. This practice, though, is beginning to undergo change, where in some countries, particularly the United States of America, it is becoming more and more common to combine confirmation with First Holy Communion. ${ }^{28}$ The second model, contained in the Rite of Christian Initiation of Adults (RCIA), is used in mission countries but also in those which are traditionally known as Christian. This model of initiation has taken on great significance in the United States of America and includes persons of varying ages and situations, but particularly noteworthy is the implementation of the fourth chapter of the RCIA. It is dedicated to preparing for confirmation and the Eucharist adults who were baptized as children (often in other Christian denominations) but who have not received proper instruction in the Faith.

A theologian who dealt with the issue of the current models of Christian initiation is Salvatore Marsili. ${ }^{29} \mathrm{He}$ describes the model based on the Ordo Baptismi Parvulorum with the terms "semblances" and "the ritual model of Christian initiation" which serves as a "pedagogical model" of the whole course of initiation. The first two terms (semblances and ritual model) refer to the process itself of the rite of baptism of infants, and includes the threestep process of initiation in a purely ritual manner. The term "pedagogical model" indicates the process of Christian initiation which is begun with infant baptism and extended over time, and does not observe the theological

\footnotetext{
${ }^{28}$ An example of this is the Diocese of Phoenix Arizona: EWTN. Global Catholic Network, accessed 21.02.2019, http://www.ewtn.com/library/bishops/ordsacinit.htm.

${ }^{29}$ Cf. Bogusław Migut, Znaki Misterium Chrystusa. Historiozbawcze ujęcie sakramentów wedlug Salvatore Marsilego OSB (1910-1983) (Lublin: Redakcja Wydawnictw KUL, 1996); Muroni, "Kolejność udzielania sakramentów," 325-326, 362.
} 
order of the sacraments (baptism-confirmation-Eucharist). Marsili sees the Ordo Initiationis Christianae Adultorum of 1972 as a balanced model for the rites of Christian initiation. The justification for this valuation is the initiation process itself, with four phases and three levels, but also with the sacraments (baptism-confirmation-Eucharist) conferred in one liturgical celebration, most often during the Easter Vigil liturgy. The introductions to both rituals feature the general principles of initiation: De Initiatione Christiana Praenotanda Generalia (in Polish, Wtajemniczenie chrześcijańskie. Wprowadzenie ogólne ${ }^{30}$ in English, Christian Initiation: General Introduction), and after these, the Rite of Baptism of Infants includes Baptism of Infants: Pastoral-Theological Introduction (nos. 1-31), ${ }^{31}$ and the Rite of Christian Initiation for Adults has Christian Initiation for Adults: PastoralTheological Introduction (nos. 1-67). ${ }^{32}$ Marsili sees great theological significance in the general introduction found in both rites but takes a critical approach to the pastoral-theological introduction in the Rite of Baptism of Infants, charging it with not making a clear connection to the further stages of initiation. He especially criticizes, however, the current model of infant baptism, in which the child receives baptism through the faith of the Church, but not through the personal faith of the parents or of others close to the child. This is called the service of "Catholicity," being more a function of vague religious tradition and not of living Christian faith. Recognizing his statements as very accurate, I would also like to point out that the service of this "Catholicity" is transmitted to the other sacraments of initiation as well, and possibly even to the majority of our pastoral ministry. Another reason for criticizing this form of initiation beginning with baptism and then leading to First Communion and confirmation, is the loss of their theological sequence (baptism-confirmation-Eucharist). The final objective of initiation, but also one of its elements, is-as Marsili says-the Eucharist, not confirmation. Currently only the model for initiation of adults insures this sequence. Baptism is the sacrament of Christian initiation, the summit of which is the Eucharist. Only baptism includes one in the reality of the Church as the mystery of salvation. Marsili immediately adds however that confirmation and the Eucharist are needed for full inclusion in the Church. From the point of view of the law baptism is the only sacrament essential for

\footnotetext{
${ }^{30}$ Obrzędy chrztu dzieci dostosowane do zwyczajów diecezji polskich (Katowice: Księgarnia św. Jacka, 1987), 9-18; Obrzędy chrześcijańskiego wtajemniczenia dorostych dostosowane do diecezji polskich (Katowice: Księgarnia św. Jacka, 1988), 9-18.

${ }^{31}$ Obrzędy chrztu dzieci, 19-29.

${ }^{32}$ Obrzędy chrześcijańskiego wtajemniczenia dorostych, 19-40.
} 
belonging to the Church - the People of God. Such phrasing is acceptable but only and exclusively in the legal sense. ${ }^{33}$ To be in the Church or to be Church implies the necessity of full Christian initiation. Ecclesiology referring to baptism alone as the sacrament of inclusion in the Church is more about law than about theology. ${ }^{34}$ The fact of recognizing only baptism as the sacrament of inclusion in the mystery of Christ and His Church, treating confirmation, but not the Eucharist, as the fulfillment or summit of initiation, provokes the opposition of Marsili and many other theologians against this most commonly-used model of Christian initiation today. ${ }^{35}$

For a fuller understanding of the Eucharist as a sacrament of Christian initiation it is necessary - as was stated at the beginning of this article - to supplement the historical-theological aspect with theological-liturgical content. At the starting point of the theological-liturgical approach, Christian initiation needs to be shown, and in it chiefly the Eucharist, as union with Christ and the entry into the mystery of Christ until the time of participating in its eschatological fulfillment. It is necessary to discover the Eucharist as an initiation into communion with Christ and through this, into man's transformation on the model of Christ. The presentation of the mysteries of the life of Jesus in relation to the Paschal Mystery as well as to worshiping the human nature of Jesus Christ at the right hand of the Father as the personal fulfillment of Jesus in His humanity lead to this purpose. The third step is to show the Eucharist as the full initiation into the Church and its mission of consecrating the world. The last element of the answer to the questions posed on the initiative character of the Eucharist is an effort at revealing the eschatological dimension and its relationship to initiation.

\section{BIBLIOGRAPHY}

Arocena Solano Félix María. "Eucharystia - pełnia inicjacji chrześcijańskiej." In Żyć w Chrystusie wedtug Ducha. Teologia sakramentów wtajemniczenia chrześcijańskiego. (Modlitwa Kościoła 17), edited by Krzysztof Porosło, 153-168. Tyniec: Wydawnictwo Benedyktynów, 2014.

Catechismus ex decreto Concilii Tridentini ad parochos Pii Quinti Pont. Max. iussu editus ad editionem Romae a.d. MDLXVI. publici iuris factam accuratissime expressus: cum s. rev. consistorii catholici per regnum saxoniae aprobatione. Lipsiae: Ex Officina Bernhardi

\footnotetext{
${ }^{33}$ Cf. Salvatore MARsiLI, I due modelli rituali dell'iniziazione cristiana. Analisi e rapporto, in: Iniziazione cristiana. Problema della Chiesa di oggi. Atti della IV Settimana di studio dell'Associazione Professori di Liturgia: Paestum 1-5 settembre 1975, (Studi di Liturgia 4) (Bologna: EDB, 1976), 159.

${ }^{34}$ Ibid.

${ }^{35}$ Cf. Migut, Znaki misterium Chrystusa, 119-120.
} 
Tauchnitz, 1865 (Polish translation: Katechizm rzymski z wyroku świętego Soboru Trydenckiego ułożony z rozkazu Piusa V Papieża i od Klemensa XIII szczególnie zalecony. T. 1-3. Warszawa: [Drukarnia Kommissyi Rząd. W. R. i O. P.], 1827).

Dokumenty Soborów Powszechnych. Tekst taciński i polski. T. 4/2: (1511-1870) Lateran V, Trydent, Watykan I, edited by Arkadiusz Baron and Henryk Pietras. Kraków: Wydawnictwo WAM, 2007.

Kelly, J[ohn] N[orman] D[avidson]. Poczatki doktryny chrześcijańskiej. Translated by Julia Mrukówna. Warszawa: Instytut Wydawniczy PAX 1988. Translated from: Early Christian doctrines. $3^{\text {rd }}$ Revised Edition. New York: HarperOne, 1978.

Kilmartin Edward J. Sacramental Theology: The Eucharist in Recent Literature. „Theological Studies" 32 (1971), no. 2: 233-277.

KraKowIAK, Czesław. Bierzmowanie sakrament inicjacji chrześcijańskiej. Lublin: Wydawnictwo Archidiecezji Lubelskiej "Gaudium," 2005.

LAMERI, Angelo. "Il sacramento della confermazione. Evoluzione storica della prassi sacramentale dell'iniziazione cristiana e criteri teologico-pastorali circa la scelta dell'età di conferimento." Rivista Liturgica 91 (2004): 83-105.

Le Liber ordinum en usage dans l'église wisigothique et mozarabe d'Espagne du cinquième au onzième siècle. Publié pour la première fois, edited Marius Férotin. Paris: Firmin-Didot, 1904.

Le pontifical Romain au moyen-âge. T. 3: Le Pontifical de Guillaume Durand. (Studi e Testi 88), edited by Michel Andrieu. Città del Vaticano: Biblioteca Apostolica Vaticana, 1940.

Les „Ordines Romani” du haut moyen âge. T. 2: Les textes (Ordines I-XIII), edited by Michel Andrieu. Louvain: Spicilegium Sacrum Lovaniense, 1971.

Les pontifical Romain au moyen-âge. T. 1: Le Pontifical de la Curie Romaine au XIIIe siècle. (Studi e Testi 87), edited by Michel Andrieu. Città del Vaticano: Biblioteca Apostolica Vaticana, 1940

MACCARRONE, Michele. "L'unità del battesimo e della Cresima nelle testimonianze della liturgia Romana dal III al XVI secolo." Lateranum 51 (1985): 88-152.

MARSILI, Salvatore. "I due modelli rituali dell'iniziazione cristiana. Analisi e rapporto." In Iniziazione cristiana. Problema della Chiesa di oggi. Atti della IV Settimana di studio dell' Associazione Professori di Liturgia: Paestum 1-5 settembre 1975. (Studi di Liturgia 4), 143 167. Bologna: Edizioni Dehoninae Bologna, 1976.

MegGer, Andrzej. "Eucharystia w procesie wtajemniczenia chrześcijańskiego." Roczniki Teologiczne 63 (2016), fasc. 8: 21-41. DOI: http://dx.doi.org/10.18290/rt.2016.63.8-2

Migut, Bogusław. Znaki Misterium Chrystusa. Historiozbawcze ujęcie sakramentów wedtug Salvatore Marsilego OSB (1910-1983). Lublin: Redakcja Wydawnictw KUL, 1996.

Muroni, Pierangelo. "Kolejność udzielania sakramentów inicjacji chrześcijańskiej." In Żyć w Chrystusie wedlug Ducha. Teologia sakramentów wtajemniczenia chrześcijańskiego. (Modlitwa Kościoła 17), edited by Krzysztof Porosło, 287-364. Tyniec: Wydawnictwo Benedyktynów, 2014.

Obrzędy chrześcijańskiego wtajemniczenia dorostych dostosowane do diecezji polskich. Katowice: Księgarnia św. Jacka, 1988.

Obrzędy chrztu dzieci dostosowane do zwyczajów diecezji polskich. Katowice: Księgarnia św. Jacka, 1987.

RAMIS, Miquel Gabriel. La iniciación cristiana en la liturgia hispánica. Bilbao: Estudios Grafite, 2001.

Rite of Baptism for Children. Washington, D.C.: United States Catholic Conference, 1969. 
Rite of Christian Initiation of Adults. Washington, D.C.: United States Catholic Conference '1988

SOBECZKO. Helmut Jan. "Eucharystia sakramentem permanentnej inicjacji chrześcijańskiej." In Misterium Eucharystii. Teologia - liturgia - ekumenizm. Encyklika Jana Pawła II „Ecclesia de Eucharistia," edited by Władysław Nowak, 52-70. Olsztyn: Wydawnictwo Uniwersytetu Warmińsko-Mazurskiego, 2004.

Tomasz z Akwinu. Summa Theologiae. Corpus Thomisticum. S. Thomae de Aquino Opera omnia. Accessed 29.05.2019. http://www.corpusthomisticum.org/iopera.html.

ZACHARA, Maciej. L'ordine dei sacramenti dell'iniziazione cristiana. La storia del loro conferimento nella liturgia romana fino alla fine del XIII secolo. (Tesi - Pontificio Ateneo San Anselmo. Pontificio Istituto Liturgico 299). Lublin: Drukarnia Liber, 2003.

ZACHARA, Maciej, "Il sacramento della confermazione nel primo millennio in Occidente." In La cresima. Atti del VII Congresso Internazionale di Liturgia. Roma, Pontificio Istituto Liturgico, 6-8 maggio 2004. (Studia Anselmiana, 144. Analecta liturgica, 26), edited by Ephrem Carr, 103-132. Roma: Pontificio Ateneo San Anselmo, 2007.

\section{EUCHARYSTIA JAKO SAKRAMENT INICJACJI CHRZEŚCIJAŃSKIEJ - ASPEKT HISTORYCZNOLITURGICZNY}

\section{Streszczenie}

Autor artykułu podejmuje problematykę miejsca Eucharystii w inicjacji chrześcijańskiej w aspekcie historycznoliturgicznym. Zwraca uwagę na obecną w pierwszym tysiącleciu zasadniczą świadomość jedności i właściwej kolejności sakramentów inicjacji chrześcijańskiej: chrzest -bierzmowanie-Eucharystia. Jej zanik zauważa na przełomie XII i XIII wieku wraz z odejściem od praktyki Komunii św. dzieci. Wskazuje, że w okresie potrydenckim doszło do odwrócenia kolejności udzielania sakramentów inicjacji chrześcijańskiej: chrzest-Eucharystia-bierzmowanie, a ten stan utrwalił dekret Quam singulari (1910), który jeszcze bardziej oddzielił od siebie te sakramenty. Autor zwraca uwagę, że powstałe po Soborze Watykańskim II dwa modele inicjacji chrześcijańskiej związane są z Ordo baptismi parvulorum (1969), określającym praktykę chrztu dzieci, po którym po kilku latach następuje I Komunia, a w późniejszym czasie - bierzmowanie, oraz z Ordo initiationis christianae adultorum (1972), dotyczącym przygotowania do bierzmowania i Eucharystii dorosłych. Odwołując się do poglądów Salvatore Marsilego, autor artykułu dokonuje oceny modeli. Za pełnowartościowy uznaje ten związany z Ordo initiationis christianae adultorum, w którym punktem docelowym jest Eucharystia. Model ten zachowuje teologiczną kolejność sakramentów i traktuje Eucharystię, a nie bierzmowanie, jako dopełnienie i szczyt inicjacji chrześcijańskiej. Pozwala także na właściwe określenie chrztu jako sakramentu włączającego w misterium zbawienia, wymagającego jednak bierzmowania i Eucharystii do pełnego włączenia w rzeczywistość Kościoła.

Słowa kluczowe: Eucharystia; chrzest; bierzmowanie; inicjacja chrześcijańska; Jezus Chrystus; Kościół; Salvatore Marsili OSB. 